\title{
ARBUSCULAR MYCORRHIZAL FUNGI IN THE CERRADO BIOME: EFFECTS OF LAND USE SYSTEM, SOIL TEXTURE, AND SEASONALITY ${ }^{1}$
}

\author{
ANDRÉIA MARCILANE AKER ${ }^{2}$, ANA LUCY CAPRONI ${ }^{2}$, RICARDO LUIS LOURO BERBARA ${ }^{3}$, JOSÉ RODOLFO \\ DANTAS DE OLIVEIRA GRANHA ${ }^{2}$, CRISTIANE FIGUEIRA DA SILVA ${ }^{3}$, MARCOS GERVASIO PEREIRA $^{3 *}$
}

\begin{abstract}
The objective of this study was to identify communities of arbuscular mycorrhizal fungi (AMF) in soils under pasture, silvopasture, and Cerrado forest ecosystems, and evaluate the effects of land use system, soil texture, and seasonality on the dynamics of AMF communities, in Alta Floresta D'Oeste, Rondônia, Brazil. Samples of the soil 0-20 cm layer were randomly collected in each ecosystem in July, 2010 (dry season) and January, 2011 (rainy season). Spores were extracted, counted, and identified. The spore density and density of each species of AMF were estimated. The frequency of occurrence, Shannon diversity index, and Simpson diversity index were calculated for each species. Multivariate clustering analysis was carried out, considering the number of AMF of each species. The results showed a trend of higher number of spores in the Cerrado forest ecosystem, regardless of the soil texture or season, when compared to pasture and silvopasture areas. The Glomus macrocarpum species presented $100 \%$ frequency of occurrence in the rainy season in both soil textures. The effects of texture and seasonality on the composition and diversity of AMF communities was more expressive in the Cerrado forest ecosystem. The climate, soil texture, and land use and management affected the composition and diversity of AMF species.
\end{abstract}

Keywords: Agroecosystems. Diversity of species. Diversity indexes.

\section{FUNGOS MICORRÍZICOS ARBUSCULARES NO CERRADO: INFLUÊNCIA DO SISTEMA DE USO, TEXTURA DO SOLO E SAZONALIDADE}

\begin{abstract}
RESUMO - O objetivo deste estudo foi identificar as comunidades dos fungos micorrízicos arbusculares (FMAs) presentes em solos sob ecossistemas de silvipastagens, pastagens e mata de cerrado, além de avaliar a influência do sistema de uso do solo, textura do solo e da sazonalidade na dinâmica das comunidades destes fungos, no município de Alta Floresta D’Oeste - RO. As amostras de terra foram coletadas aleatoriamente na profundidade de 0 a $20 \mathrm{~cm}$, em cada um dos ecossistemas em Julho/2010 (período seco) e Janeiro/2011 (período chuvoso). Após extraídos, os esporos foram contados e identificados. Estimou-se a densidade dos esporos e a densidade de cada espécie de FMA. Calcularam-se a frequência de ocorrência de cada espécie, o índice de diversidade de Shannon e o índice de diversidade de Simpson. Realizou-se uma análise multivariada de agrupamento baseado no número de indivíduos das espécies dos FMAs. Houve tendência de um maior número de esporos no ecossistema de mata de Cerrado independente da textura do solo ou da estação do ano, quando comparado as áreas de pastagem e silvipastagem. A espécie de Glomus macrocarpum apresentou 100\% de frequência de ocorrência na estação chuvosa em ambas as texturas do solo. A influência da textura e da sazonalidade na composição e diversidade da comunidade dos FMAs foi mais expressiva no ecossistema de mata de Cerrado. O clima, a textura do solo, o manejo e o sistema de uso do solo afetam a composição e diversidade de espécies de FMAs.
\end{abstract}

Palavras-chave: Agroecossistemas. Diversidade de espécies. Índices de diversidade.

\footnotetext{
${ }^{*}$ Corresponding author

${ }^{1}$ Received for publication in $08 / 22 / 2020$; accepted in $08 / 16 / 2021$.

Paper extracted from the monography of the first author.

${ }^{2}$ Department Academic of Social and Environmental Sciences, Universidade Federal de Rondônia, Guajará Mirim, RO, Brazil; eng.aaker@gmail.com - ORCID: 0000-0001-5745-8723, analucycaproni@yahoo.com.br - ORCID: 0000-0002-7795-3075, rodgranha@gmail.com - ORCID: 0000-0002-1007-3997.

${ }^{3}$ Department of Soil, Universidade Federal Rural do Rio de Janeiro, Seropédica, RJ, Brazil; rberbara@yahoo.com.br - ORCID: 0000-00029133-7754, cfigueirasilva@yahoo.com.br - ORCID: 0000-0003-4606-3149, gervasio@ufrrj.br - ORCID: 0000-0002-1402-3612
} 


\section{INTRODUCTION}

The conversion of native forests into pasture has caused impoverishment and degradation of soils in the Amazon region due to several factors, mainly the lack of suitability of soils for the livestock activity. However, the balance between vegetation and soil biological component is essential for the maintenance of soil fertility, and facilitate nutrient cycling (MIRANDA; SILVA; SAGGIN-JUNIOR, 2010). Silvopasture systems have been used for the maintenance of economic activities related to animal breeding and production; it provides a better interrelation between biotic (soil vegetation and microorganisms) and abiotic (soil, air layer on the soil, soil water, rainfall water intercepted by the vegetation and soil surface) components of the ecosystem (WHEATERS; STRAVER; LIKENDS, 2015).

Silvopasture systems present better performance for the maintenance of associations between trees, pastures, and animals, resulting in better soil physical, chemical, and biological characteristics (BARROS et al., 2018; LOSS et al., 2014). Thus, these systems contribute to improve yields of farms, due to the management of natural resources (JOSÉ; DOLLINGER, 2019), contributing to avoid soil degradation, and recover degraded areas (PEZARICO et al., 2013). According to Nicodemo et al. (2004), land use systems should include a high number of plant species in a same crop or successions, high organic matter levels, high diversity of soil organisms, and high water, light, and nutrient use efficiencies to maintain the soil production, thus forming an appropriate environment for the activity of microorganisms related to ecosystem stability.

Information on dynamics of microorganisms, such as arbuscular mycorrhizal fungi (AMF) in different soils types and climatic seasons, can be a useful alternative to evaluate the quality of pasture ecosystems combined with forest plantations, and understand edaphic and climate factors that affect AMF communities. AMF assist in nutrient absorption processes of plants, mainly nutrients that are at low levels in the soils (CHEN et al., 2018), and contribute to the formation and stability of soil aggregates, through its mycelium and glomalin productions, thus reestablishing the soil structure (BARBOSA et al., 2019). AMF contribute to the efficiency in nutrient cycling process, and development and succession of plants, improving the establishment of plants species at intermediate and advanced succession stages, and the recovery of the plant cover at climax stage (SOUSA et al., 2014). Therefore, AMF present environmental benefits and are characterized as a useful biotic resource for sustainable soil management (CHEN et al., 2018), by ensuring the maintenance of plant biodiversity and ecosystem functions.
The objective of this study was to identify AMF communities in soils with vegetation characteristic of Cerrado, encompassing pasture, silvopasture, and Cerrado forest ecosystems, and evaluate the effects of land use system, soil texture, and seasonality on the AMF communities in Alta Floresta D'Oeste, Rondônia, Brazil.

\section{MATERIAL AND METHODS}

Samples of the soil $0-20 \mathrm{~cm}$ layer were randomly collected in pasture, silvopasture, and Cerrado forest areas in Alta Floresta D'Oeste, Rondônia, Brazil $\left(12^{\circ} 25^{\prime} 51^{\prime \prime S}\right.$, and $62^{\circ} 04^{\prime} 43^{\prime \prime} \mathrm{W}$, and 360 meters of altitude). The region presents an AM, tropical hot and wet climate, according to the Köppen classification. The mean total annual rainfall depths vary from 1,750 to $2,250 \mathrm{~mm}$, with a rainy season from October to May and a dry season from June to September, and mean annual potential evapotranspiration of $1,455 \mathrm{~mm}$. The lowest rainfall indexes are found between May and September. The mean annual temperature is $25.8{ }^{\circ} \mathrm{C}$ and the relative air humidity varies from $63 \%$ to $95 \%$ (CUNHA; SCHÖFFEL, 2011).

The ecosystems presented soils with clayey and sandy textures. The soil samples were collected for analysis of diversity of species and densities of AMF spores in two seasons, July 2010 (dry season) and January 2011 (rainy season).

The predominant species in the pasture and silvopasture ecosystems was Urochloa brizantha A. Rich. The vegetation of the silvopasture ecosystem included the arboreal species: Cedrela fissilis Vell.; Schizolobium amazonicum Huber ex. Ducke; and Platonia insiginis Mart.) in the sandy texture soil, and Myracroduon urundeuva (Freire Allemão) Engler.; and P. insiginis Mart) in the clayey texture soil. The Cerrado forest ecosystem presented a wide diversity of species, with typical characteristics of the Cerrado biome.

The sampling consisted in the collection of eight composite samples formed by 10 subsamples in each ecosystem, totaling 48 composite samples in each season (July, 2010 and January, 2011). The samples were analyzed at the Laboratory of Microbiology of the Federal University Foundation of Rondônia (UNIR), in Rolim de Moura, RO, Brazil.

The sand, silt, and clay percentages and $\mathrm{pH}$ values of the soils in the ecosystems were evaluated according to Donagema et al. (2011).

AMF spores were extracted from $100 \mathrm{~mL}$ of each soil sample by the wet sieving method (GERDEMANN; NICOLSON, 1963), with centrifugation in saccharose $50 \%\left(\mathrm{v} \mathrm{v}^{-1}\right)$. The spores were transferred to a channeled Petri dish, counted, and grouped by size, color, and form. These spores were placed in slides in two groups, one with 
polyvinyl alcohol in lactoglycerol (PVLG) and other in Melzer reagent, and broken under coverslips to expose the internal walls. The spores were then identified and counted by species.

The AMF species were identified based on observations in an optical microscope with clear illumination and immersion objective, according to Schenck and Perez (1988) and morphologically described according to data available at the webpages of the International Culture Collection of Arbuscular Mycorrhizal Fungi (INVAM, 2000), International Culture Collection of Glomeromycota (CICG), and recent scientific literature. The taxonomic characters used to differentiate the species included number and type of layers of spore walls, internal wall morphological characteristics (when present), spore support hypha morphology, and color and size variation.

The spore density and density of each AMF species were estimated. The first was determined by the number of spores in $100 \mathrm{~mL}$ of soil, and the second by the number of spores of the same species in $100 \mathrm{~mL}$ of soil.

The frequency of occurrence of each species was calculated for each sampling season (dry and rainy), according to the equation $F i=J i / K$, where $F i=$ frequency of occurrence of species $i ; J i=$ number of samples with occurrence of the species $i$, and $k=$ total number of samples.

The Shannon Wiener (H') and Simpson dominance (S) indexes were calculated to analyze communities in each soil sample. The Shannon diversity index was calculated according to the equation: $H^{\prime}=-\sum\left(X_{i} / X_{o}\right) \times \log \left(X_{i} / X_{o}\right)$, where $X_{i}$ is the spore density of each species in $100 \mathrm{~mL}$ of soil; $X_{o}$ is the total spore density of all species. The Simpson dominance index was calculated by the equation $S=\sum\left(X_{i} / X_{0}\right)^{2}$, where $\mathrm{X}_{\mathrm{i}}$ and $\mathrm{X}_{\mathrm{o}}$ are as described above.

The results of spore density were subjected to parametric test, Tukey $(\mathrm{p}<0.05)$; and non-parametric test, Mann-Whitney $(\mathrm{p}<0.05)$, using the Assistat 7.7 program. Multivariate clustering analysis was carried out using the PAST program, paired comparison method, and Gower similarity measure.

\section{RESULTS AND DISCUSSION}

\section{AMF Spore Density}

The distribution of number of AMF spores in clayey and sandy texture soils of the pasture, silvopasture, and Cerrado forest ecosystems in the dry (July, 2010) and rainy (January, 2011) seasons are presented in Figure 1. The soil texture (Table 1) affected the spore density, mainly in the Cerrado forest areas, whose sandy texture allows for a higher AMF sporulation in both dry and rainy seasons (Figure 1A). Vieira et al. (2020) found that the higher the clay content, the lower the abundance of AMF spores in soils with textural gradient; they evaluated soils in mountain top areas in the Semiarid region of the Caatinga biome, and report that sandy soils present larger particles, which facilitates root expansion and probably generates a better distribution of AMF propagules than clayey soils. In addition, sandy soils have larger porous spaces that favor the metabolic processes of these microorganisms. The lower water retention capacity of sandy soils may have also affected sporulation. According to Bonfim et al. (2010), low water availability induces manifestation of adaptation mechanisms in microorganisms associated to plants, such as increase in sporulation.

The pasture areas presented no difference between textural classes (Figure 1A). Silvopasture areas presented a trend of higher sporulation in the sandy texture soil in the dry season, but with no significant difference; and the clayey texture soil presented higher sporulation in the rainy season (Figure 1A). This indicates that the land use and management and season can affect responses of AMF sporulation to soil texture. Concentrations of AMF propagules tend to be higher in the soils with sandy texture, however, the vegetation composition and land use system may change the structure of AMF communities (CARVALHO et al., 2012; VIEIRA et al., 2020).

The effect of seasonality on mean spore density (Figures 1B and 1C) within each ecosystem was found only for the silvopasture area in the sandy texture soil, with significantly lower AMF sporulation in the rainy than in the dry season (Figure 1C). This denotes that land use and management and soil texture affect the AMF sporulation response to climatic variations. MoebiusClune et al. (2013) reported that the soil moisture can explain variations between seasons, since a low water availability to host plants can stimulate AMF sporulation; and that soil moisture and texture are usually related, since soils with coarser textures tend to be more drained (BONFIM et al., 2010). Pereira et al. (2018) evaluated soils under different management practices in the Atlantic Forest biome, in the Northeast region of Brazil and found higher number of spores in the dry when compared to the rainy season.

Regarding the effect of land use and management on AMF sporulation, clayey texture soils of the pasture and silvopasture ecosystems presented similar AMF spore density in both seasons, with lower sporulation than those found in the Cerrado forest areas (Figure 1B). Sandy texture soil presented this same result in the rainy season, but significant differences between areas in the dry season, with the lowest sporulation in the pasture, intermediate sporulation in the silvopasture, and the highest sporulation in the Cerrado forest ecosystem (Figure 1C). 


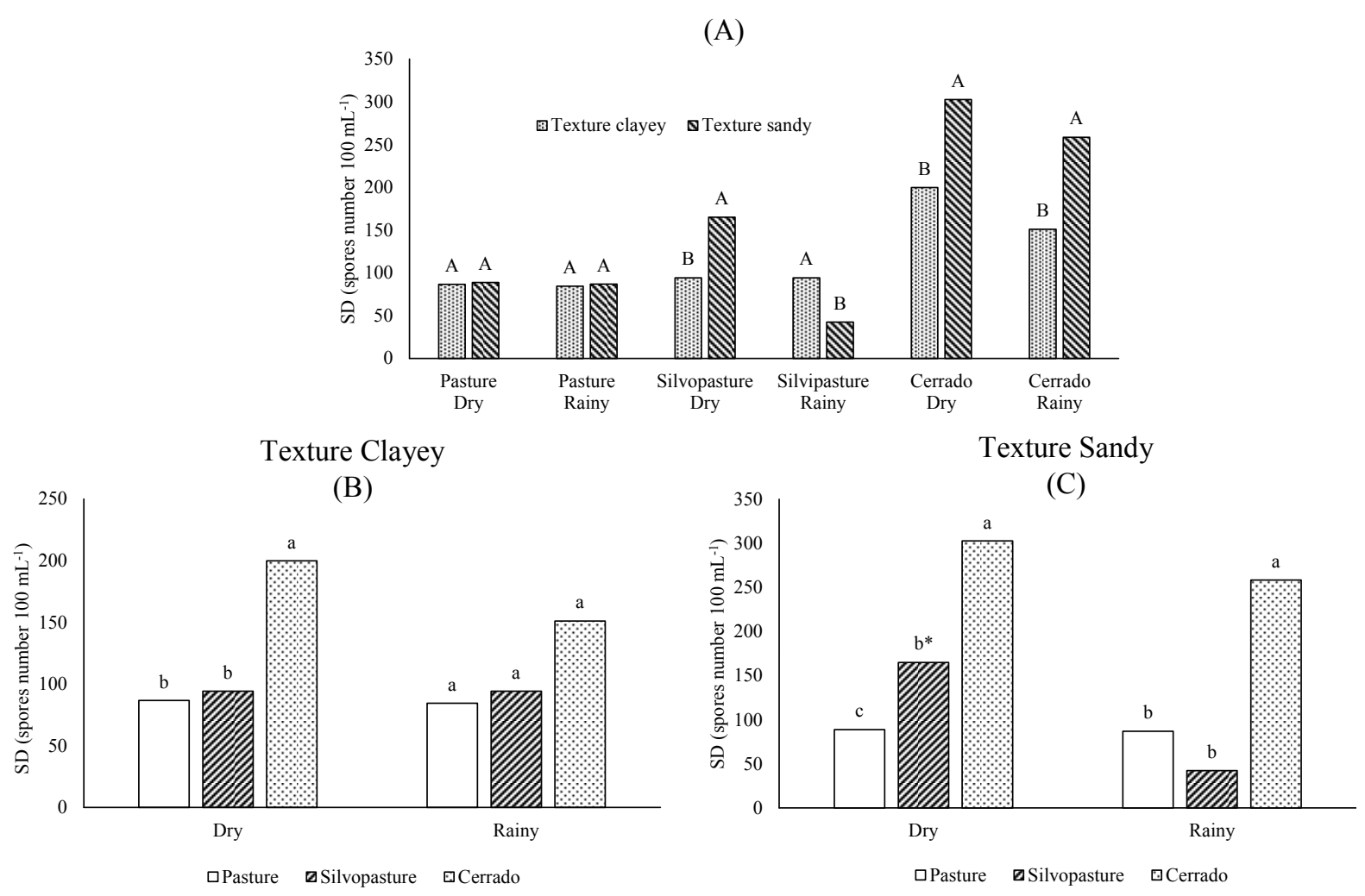

Figure 1. Mean AMF spore density (SD) in $100 \mathrm{~mL}$ of soils from pasture, silvopasture, and Cerrado forest ecosystems with clayey and sandy textures (A); and ecosystems with clayey (B) and sandy (C) texture soils in the dry (July, 2010) and rainy (January, 2011) seasons. Columns with the same uppercase letter within the same ecosystem comparing soil textures, or lowercase letters within the same season comparing ecosystems are not different from each other by the Tukey's test at 5\% probability level. $*=$ significant difference between seasons within the same ecosystem.

Table 1. Sand, silt, and clay percentages and $\mathrm{pH}$ of soil samples from pasture, silvopasture, and Cerrado forest ecosystems. Alta Floresta D'Oeste, Rondônia, Brazil.

\begin{tabular}{lcccc}
\hline \multirow{2}{*}{\multicolumn{1}{c}{ Ecosystem }} & Sand & Clay & Silt & \\
& \multicolumn{4}{c}{$\mathrm{g} \mathrm{kg}^{-1}$} \\
\cline { 2 - 5 } & & Texture sandy & \\
\hline Pasture & 760 & 180 & 50 & 5.8 \\
Silvopasture & 740 & 100 & 160 & 5.2 \\
Cerrado forest & 830 & 120 & 50 & 5.1 \\
\hline & & Texture clayey & 5.8 \\
\hline Pasture & 240 & 290 & 470 & 6.5 \\
Silvopasture & 390 & 340 & 270 & 5.1 \\
Cerrado forest & 320 & 270 & 410 & \\
\hline
\end{tabular}

Therefore, the Cerrado forest ecosystem showed higher spore density in both soil textures and seasons, diverging from results found in studies comparing native with anthropized areas, in which native areas presented lower sporulation (CORDEIRO et al., 2005; FERREIRA; CARNEIRO; SAGGIN JUNIOR, 2012; ASSIS et al., 2014). The difference in sporulation between areas may be due to variations in soil properties, host plant species, and AMF survival strategies (PEREIRA et al., 2018). Some plants are preferred by AMF species, affecting the multiplication of these microorganisms (COUTINHO et al., 2019a); in addition, a higher number of AMF species promotes a higher general sporulation (COUTINHO et al., $2019 \mathrm{~b}$ ). Thus, the highest number of plant species in the Cerrado forest may have contributed to the higher number of AMF species (Table 2), and the higher sporulation of some species (Table 2), reflecting in a higher total abundance of spores (Figures $1 \mathrm{~B}$ and 1C). According to Moreira and Siqueira (2006), the occurrence of a high sporulation may indicate adequate nutritional and environmental conditions for these fungi. 


\section{Composition and diversity of AMF species}

Twenty-four AMF morphotypes were identified in the soils of the pasture, silvopasture, and Cerrado forest ecosystems, in the dry and rainy seasons (Table 2). Twenty of them were identified at the species level and four at the genus level (Table 2). There was no significant difference (MannWhitney $\mathrm{P} \leq 0.05$ ) in AMF spore density between the dry and rainy seasons, within the different ecosystems.

Table 2. Mean spore density and frequency of occurrence of AMF species in $100 \mathrm{~mL}$ of samples of soils collected in the dry (DS) and rainy (RS) seasons in pasture, silvopasture, and Cerrado forest ecosystems with sandy and clayey texture soils. Alta Floresta D'Oeste, Rondônia, Brazil.

\begin{tabular}{|c|c|c|c|c|c|c|c|c|c|c|c|c|c|c|c|c|}
\hline \multirow{3}{*}{ Species } & \multicolumn{8}{|c|}{ SANDY TEXTURE SOIL } & \multicolumn{8}{|c|}{ CLAYEY TEXTURE SOIL } \\
\hline & \multicolumn{2}{|c|}{ Silvopasture } & \multicolumn{2}{|c|}{ Pasture } & \multicolumn{2}{|c|}{ Cerrado } & \multicolumn{2}{|c|}{$\mathrm{FO}$} & \multicolumn{2}{|c|}{ Silvopasture } & \multicolumn{2}{|c|}{ Pasture } & \multicolumn{2}{|c|}{ Cerrado } & \multicolumn{2}{|c|}{ FO } \\
\hline & DS & $\mathrm{RS}$ & DS & RS & DS & RS & DS & $\mathrm{RS}$ & DS & $\mathrm{RS}$ & DS & $\mathrm{RS}$ & DS & $\mathrm{RS}$ & DS & RS \\
\hline Acaulospora & & & & & & & & & & & & & & & & \\
\hline A. rehmii & - & 0.9 & - & - & 3.1 & 1.6 & 12.5 & 16.6 & - & 0.3 & - & - & - & - & 4 & 4 \\
\hline A. mellea & 12.1 & 4.8 & 4.1 & 13.7 & 64.6 & 5.1 & 66.6 & 4 & 5.5 & 4.9 & 5.9 & 2.0 & 21.5 & 7.7 & 58 & 54 \\
\hline A. denticulata & 2.1 & - & 1.1 & - & - & - & 12.5 & 0 & - & - & - & - & - & - & - & - \\
\hline A. excavata & - & 9.5 & - & 3.5 & - & - & 8 & 37.5 & 0.2 & 2.4 & 0.7 & 0.7 & 0.62 & 3.5 & 12.5 & 25 \\
\hline A. morrowiae & - & - & - & 0.1 & - & - & 4 & 4 & - & 1 & - & - & - & - & 12.5 & 12.5 \\
\hline Acaulospora sp. & - & - & - & - & - & - & - & - & - & - & - & - & - & 3.5 & - & 4 \\
\hline A. scrobiculata & 14.4 & 5.1 & 7.6 & 1.5 & 41.6 & 15.4 & 66.6 & 62.5 & 1.9 & 0.9 & 7.1 & 1.2 & 36 & 9.7 & 54 & 25 \\
\hline $\begin{array}{l}\text { A. tuberculata } \\
\text { Claroideoglomus }\end{array}$ & - & - & - & - & 2.6 & - & 8 & - & - & - & - & - & 1.87 & - & 4 & - \\
\hline $\begin{array}{l}\text { C. etunicatum } \\
\text { Sieverdingia }\end{array}$ & 14.1 & 4.6 & 17.0 & 17.3 & 4.0 & 23 & 54 & 62.5 & 13.4 & 14.0 & 5.5 & 16.1 & 15.5 & 29.2 & 66 & 79 \\
\hline Si. tortuosa & - & - & - & - & 2.1 & - & 8 & - & - & - & - & - & 1.6 & - & 4 & - \\
\hline $\begin{array}{l}\text { Non-identified } \\
\text { species } \\
\text { Funneliformis }\end{array}$ & 9.8 & 0.9 & 10.2 & 3.6 & 13.6 & 11.6 & 58.3 & 54.0 & 7.4 & 3.6 & 6.6 & 5.5 & 7.1 & 3.4 & 41 & 66 \\
\hline $\begin{array}{l}\text { F. geosporus } \\
\text { Kuklospora }\end{array}$ & - & 0.2 & - & 1.1 & - & 1.0 & 4.0 & 20.8 & - & 1.5 & - & - & - & - & - & 4 \\
\hline $\begin{array}{l}\text { K. colombiana } \\
\text { Glomus }\end{array}$ & - & - & - & - & - & - & - & - & 1.9 & - & - & - & - & - & 4 & - \\
\hline G. ambisporum & - & 0.2 & - & - & - & - & - & 4.0 & - & - & - & - & - & - & - & - \\
\hline G. macrocarpum & 15.5 & 11.6 & 47.6 & 35.9 & 154 & 176.5 & 87.5 & 100 & 24.4 & 59 & 48.6 & 52.4 & 47.4 & 82.6 & 83 & 100 \\
\hline $\begin{array}{l}\text { Glomus sp. } \\
\text { Paraglomus }\end{array}$ & - & - & - & - & - & - & - & - & - & 0.4 & - & - & - & - & - & 4 \\
\hline P. occultum & - & - & - & - & - & - & - & - & - & - & - & - & 6.6 & - & 4 & - \\
\hline $\begin{array}{l}\text { P. brasilianum } \\
\text { Oehlia }\end{array}$ & 8.2 & 4.1 & 0.7 & 8.6 & 9.9 & 20.8 & 62.5 & 62.5 & 20 & 2.1 & 11.6 & 4.4 & 59.3 & 7.1 & 54 & 58 \\
\hline $\begin{array}{l}\text { O. diaphana } \\
\text { Rhizoglomus }\end{array}$ & - & 0.9 & - & - & 1.0 & 2.1 & 29.0 & 8.3 & - & - & - & 1 & - & 3.6 & 16 & 20 \\
\hline $\begin{array}{l}\text { R. microaggregatum } \\
\text { Rhizophagus }\end{array}$ & - & - & - & - & 1.9 & - & 4.0 & - & - & - & - & - & - & - & - & - \\
\hline $\begin{array}{l}\text { R. fasciculatus } \\
\text { Sclerocystis }\end{array}$ & - & 0.6 & - & 1.2 & 2.9 & 1.4 & 12.5 & 16 & - & 3.5 & - & 0.3 & - & 0.6 & - & 20 \\
\hline $\begin{array}{l}\text { Sclerocystis sp. } \\
\text { Scutellospora }\end{array}$ & - & - & - & - & 1.9 & - & 4 & - & - & - & - & - & - & - & - & - \\
\hline S. projecturata & - & - & - & - & 1.4 & - & 4 & - & - & - & 0.5 & - & - & - & 4 & - \\
\hline Scutellospora sp. & - & - & - & - & - & - & - & - & - & - & - & - & 1 & - & 4 & - \\
\hline Standard deviation & $5.6^{\mathrm{ns}}$ & $96.6^{\mathrm{ns}}$ & $10.2^{\mathrm{ns}}$ & $8.2^{\mathrm{ns}}$ & $33.7^{\text {ns }}$ & $36^{\text {ns }}$ & 28 & 29 & $6.7^{\mathrm{ns}}$ & $12.1^{\mathrm{ns}}$ & $10.1^{\mathrm{ns}}$ & $11^{\mathrm{ns}}$ & $16.4^{\mathrm{ns}}$ & $13.4^{\mathrm{ns}}$ & 25.8 & 29.3 \\
\hline Total of species & 8 & 10 & 7 & 9 & 14 & 10 & 18 & 15 & 6 & 10 & 8 & 9 & 11 & 11 & 15 & 14 \\
\hline $\begin{array}{c}\text { Total of species in } \\
\text { the ecosystems }\end{array}$ & & & 11 & & 14 & & & & 13 & & 10 & & 14 & & & \\
\hline
\end{tabular}

ns $=$ not significant between dry and rainy seasons within each ecosystem by the Mann-Whitney test $(\mathrm{p}<0.05)$. (-) absence of AMF species; FO = Frequency of occurrence.

The Cerrado forest presented a higher number total AMF species than the silvopasture and pasture ecosystems, mainly in the dry season and in areas with clayey texture soils. Areas with sandy texture soils presented 18 AMF species in the dry season and 15 species in the rainy season (Table 2); whereas the areas with clayey texture soils presented 15 and 14 species, respectively (Table 2).

The significant difference in total number of AMF species between the Cerrado forest and the other ecosystems, mainly in the dry season and in clayey soils, may be due to the more diverse flora in the Cerrado forest ecosystem. Studies have correlated the wealth of AMF species with the wealth of host plants in the ecosystem (CARVALHO et al., 2012; WINAGRASKI et al., 2019; SILVA et al., 2021). In addition, natural environments commonly present a higher number of AMF species than environments with anthropogenic disturbances (SANTOS; SCORIZA, R. N.; FERREIRA, 2013; AZEVEDO et al., 2019). Thus, the lower number of species in the pastures and silvopasture ecosystems may be connected to impacts of cattle grazing and constant pruning of trees, which result in 
disturbances with different intensities, since the pasture areas presented, in general, lower total number of species than silvopasture areas. According to Van der Heyde et al. (2017a), AMF are sensitive to disturbances, but its response is not always predictable, due to differences in type of disturbance and AMF species and growth strategies.

The lower total wealth of AMF species found in the pasture ecosystem does not necessarily represent the distribution pattern of these organisms, since pastures can stimulate, inhibit, or have no effect on AMF; it was probably due to response variables of the fungi, ambiguous effects of soil and plant responses to cattle grazing, and variations in study time, and dependent on the pasture quality and management of the livestock farms (VAN DER HEYDE et al., 2017b).

AMF of the genera Glomus and Acaulospora were found in the pasture, silvopasture, and Cerrado forest ecosystems, regardless of the soil texture and seasons. The genus Acaulospora presented a higher number of species (eight) and high frequency of occurrence (Table 2). High occurrence of the genera Glomus and Acaulospora was also found by Melo et al. (2014) in soils in the Cerrado biome. Species of the Acaulospora genus have intrinsic characteristics of production of large number of spores and high adaptability to soils with low $\mathrm{pH}$ (STÜRMER; SIQUEIRA, 2011) which is the case of most soils of the North region of Brazil and the Cerrado biome, although the $\mathrm{pH}$ of the areas evaluated in the present study varied from 5.1 and 6.5 (Table 1) and pastures with different degradation and disturbance levels (CRISTO; FORS; CARVALHO, 2018). The higher occurrence of genera Glomus and Acaulospora may be due to the highest adaptation capacity to soils subjected to variations in organic matter contents, $\mathrm{pH}$, and management, denoting that these species are resistant to environmental disturbances (WINAGRASKI et al., 2019; MAIA et al., 2020).

Five species (Acaulospora mellea, Acaulosporarsobiculata, Claroideoglomus etunicatum, Glomus macrocarpum and Paraglomus brasilianum) were found with frequency of occurrence above 54\%, considering the six ecosystems and the two sampling seasons. These species were considered as generalists in the present study (STÜRMER; SIQUEIRA, 2011; MELO et al., 2014). Regarding the occurrence, A. mellea was considered as generalist and $A$. scrobiculata as intermediate species by Cristo, Fors and Carvalho (2018) in pasture and native forest areas in the state of Santa Catarina, Brazil A. scrobiculata, A. mellea, $C$. etunicatum, and $G$. macrocarpum were considered as omnipresent and adapted to different land management systems (AZEVEDO et al., 2019; WINAGRASKI et al., 2019; MIGUEL et al., 2020).

Spores of Kuklospora colombiana, Acaulospora sp., Glomus sp., Rhizoglomus microaggregatum, Paraglomus occultum, and
Scutellospora sp. were not found in sandy texture soils; the species $K$. colombiana and $P$. occultum were found in the clayey texture soils in dry season, although with low frequency of occurrence (4\%) (Table 2). Spores of Acaulospora denticulata, Glomus ambisporum, $R$. microaggregatum, and Sclerocystis sp. were not found clayey texture soils; however, A. denticulata, R. microaggregatum, and Sclerocystis $\mathrm{sp}$. were found in sandy texture soils and in the dry season, with frequency of occurrence below $12.5 \%$ (Table 2).

Considering the species found with low frequency of occurrence, $K$. colombiana presents the highest sporulation in acid soils than in neutral or alkaline soils (MEHROTRA, 1998) and wide distribution in the ecosystems in Brazil (WINAGRASKI et al., 2019). The species $G$. ambisporum, $\quad R$. microaggregatum, and Scutellospora sp. occur in the Legal Amazon region (STÜRMER; SIQUEIRA, 2011). According to Velázquez, Cabello, and Barrera (2013), species of the Scutellospora genus are widely found in soils with sandy texture and less subject to disturbance.

Other species were sensitive only to the climate, such as $A$. tuberculata, Sieverdingia tortuosa, and Scutellospora projecturata, which occurred only in the dry season in both sandy and clayey texture soils. All species found had already been reported in different biomes in Brazil (DANTAS et al., 2015; WINAGRASKI et al., 2019; MAIA et al., 2020). A survey conducted by Maia et al. (2020) found the species $C$. etunicatum and $A$. scrobiculata in all biomes in Brazil (Amazon Forest, Atlantic Forest, Cerrado, Caatinga, Pampa, and Pantanal), and the other species found in the present study (except $P$. brasilianum, Funneliformis geosporus, Si. tortuosa, and S. projecturata) were found in at least four of these six biomes. This denotes the wide distribution of these species in Brazil and their grow capacity in different environmental conditions, since they were found in disturbed and non-disturbed areas (MAIA et al., 2020). Winagraski et al. (2019) conducted a review on AMF diversity in forest ecosystems in different biomes in Brazil and found the occurrence of $P$. brasilianum (Atlantic Forest and Cerrado), $F$. geosporus (Atlantic Foreest, Amazon Forest, and Caatinga) and Si. tortuosa (Atlantic Forest, Cerrado, and Caatinga). Despite $S$. projecturata was not reported in the surveys of Maia et al. (2020) and Winagraski et al. (2019), it was found in organic orchards in the Semiarid region of the state of Ceará (DANTAS et al., 2015).

The Shannon diversity index was, in general, higher in the Cerrado forest area, except in the rainy season in the sandy texture soil, and a lower Simpson dominance index, when compared to the other ecosystems (Figure 2). Higher variation in Shannon index between seasons was found in the Cerrado forest area, in sandy texture soil, whose diversity was 
$35 \%$ higher in the dry when compared the rainy season. The same pattern was found for the difference between textures, with the Cerrado forest area presenting a diversity $55 \%$ higher for the clayey, when compared to the sandy texture soil. However, higher variation in Simpson dominance index between seasons was found in the silvopasture area with sandy texture soil; it was approximately $37.5 \%$ higher in the rainy, when comparison the dry season. The highest variation in Simpson dominance index between soil textures was found in the Cerrado forest area in the rainy season; it was $78 \%$ higher in the sandy, when compared to the clayey texture soil.

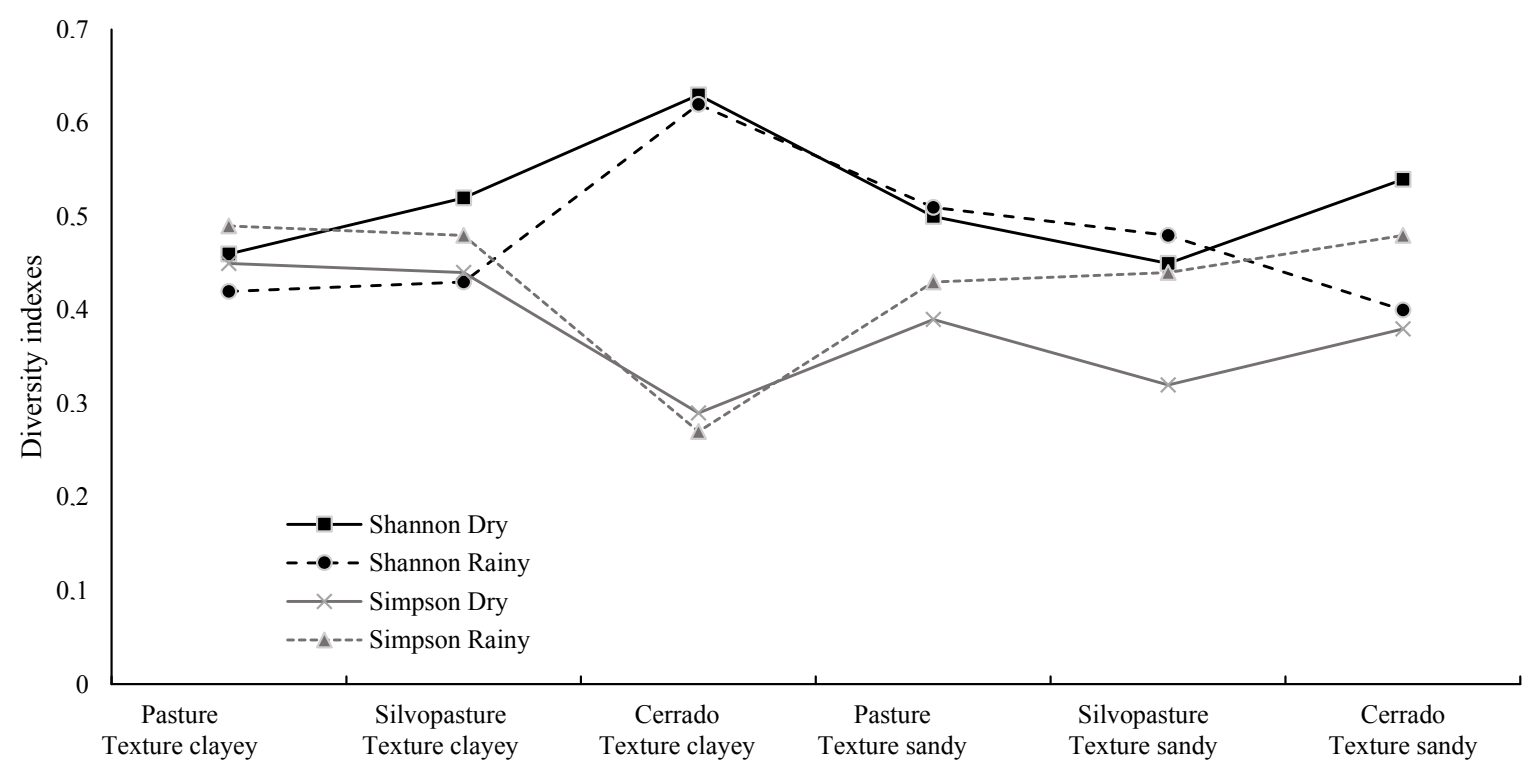

Ecosystems

Figure 2. Shannon AMF species diversity and Simpson AMF species dominance indexes in pasture, silvopasture, and Cerrado forest ecosystems, in sandy and clayey texture soils, in the dry (July 2010) and rainy (January 2011) seasons. Alta Floresta D'Oeste, Rondônia, Brazil.

The Simpson dominance index was below 0.5 in the three ecosystems and two seasons, with the lowest value in the clayey texture soil in the Cerrado forest ecosystem, in both seasons, making the Shannon-Wiever index higher in this ecosystem. This result indicates that populations of AMF species are more well distributed in the Cerrado forest, showing a higher stability than in the other ecosystems. The variations of the indexes between the dry and rainy seasons, and between soil textures were, in general, higher in the Cerrado forest.

Considering the number of AMF of each species, the hierarchical clustering analysis showed that the composition of AMF communities varies between soil textures within each season (Figure 3A and $3 \mathrm{~B}$ ), and between seasons within each soil texture (Figure 3C and 3D), in the different ecosystems, confirming the results found for the diversity and dominance indexes (Figure 1). The effect of soil texture on the composition of species was more expressive in the Cerrado forest area, and in the dry season, whose dissimilarity observed through the distance of connection between soils of sandy and clayey texture was $\sim 70 \%$. This dissimilarity was approximately 3.5 -fold higher than that between soil textures in pasture and silvopasture areas ( $\sim 20 \%$ in both areas) (Figure $3 \mathrm{~A})$. In the rainy season, the dissimilarity in the composition of AMF communities between soil textures were approximately $50 \%, 40 \%$, and $25 \%$, in the Cerrado forest, silvopasture, and pasture areas, respectively (Figure 3B)

The effect of seasonality on the composition of AMF communities in the ecosystems in each soil texture showed that the Cerrado forest area had the highest dissimilarity between seasons for the sandy $(\sim 65 \%)$ (Figure $3 \mathrm{C})$ and clayey $(\sim 50 \%)$ texture soils (Figure 3D). The dissimilarity was lower than $30 \%$ in silvopasture and pasture areas, in both soil textures. The hierarchical clustering analysis also showed that the composition of AMF communities is more similar between the pasture and silvopasture areas, standing out from the Cerrado forest area, regardless of the season or soil texture (Figure 3 ). 


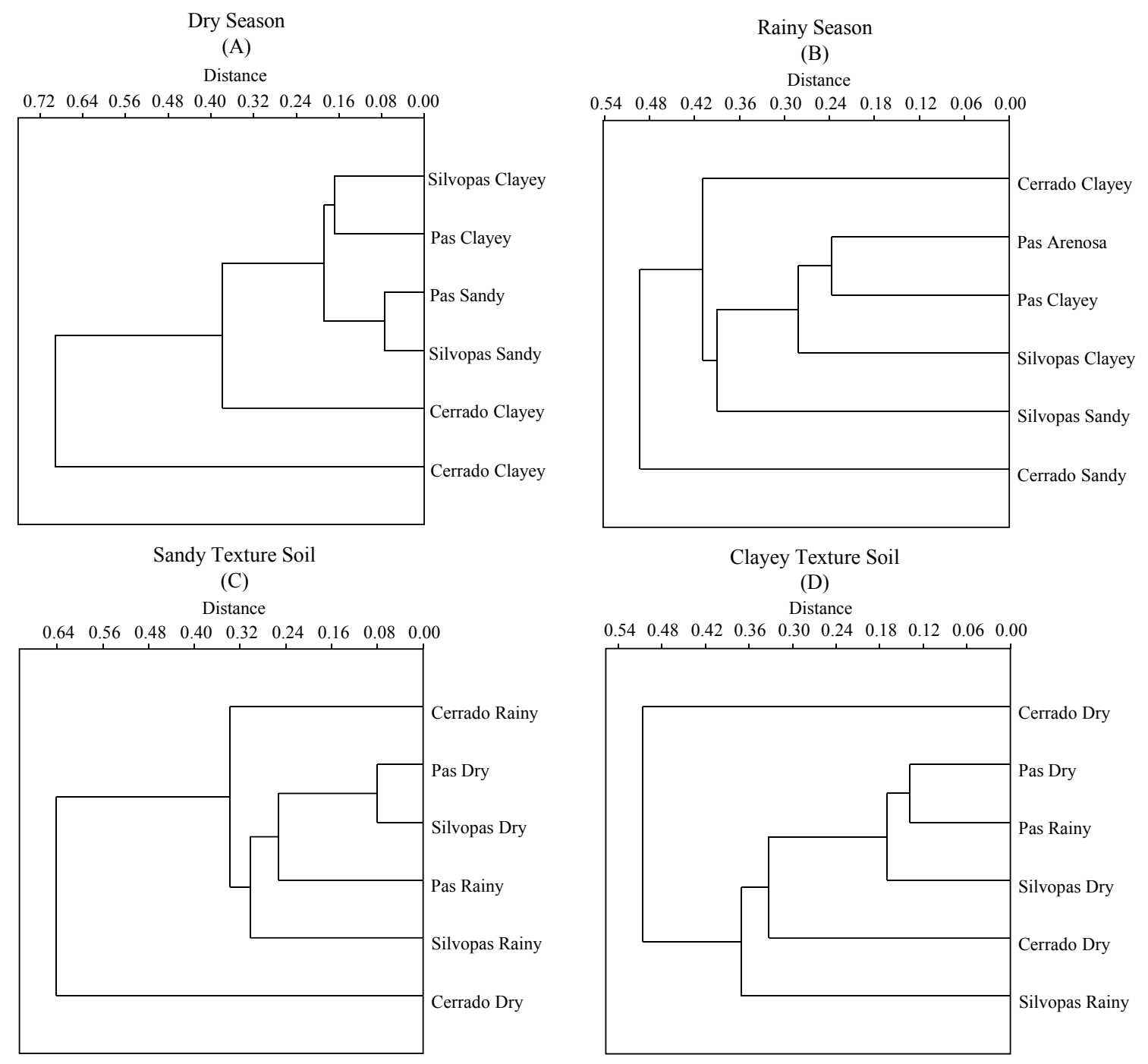

Figure 3. Hierarchical clustering analysis considering the number of AMF of each species in pasture, silvopasture, and Cerrado forest ecosystems, in the $\operatorname{dry}(\mathrm{A})$ and rainy $(\mathrm{B})$ seasons, in sandy (C) and clayey (D) texture soils.

The comparison between clayey and sandy texture soils for composition of AMF communities showed intermediate to high dissimilarity levels between communities in the Cerrado forest ecosystem, and low dissimilarity level for the pasture and silvopasture ecosystems. Therefore, although soil texture affects the distribution of AMF species, the effect varies as a function of soil cover plant and land use. The effect of seasonality on the communities presented similar results; the dissimilarity level between dry and rainy seasons was intermediate in the Cerrado forest, and low in the pasture and silvopasture areas. Vieira et al. (2020) report that some factors other than soil texture can affect the distribution of AMF species, mainly the vegetation, which is an important modeling of communities of these microorganisms. Rodrigues, Silva, and Yaho-Melo (2021) evaluated AMF in soils under native and natural regeneration vegetation and found that the type of vegetation affect more the AMF communities than the seasonality.

Determining an isolate factor that is affecting the sporulation and diversity of species is difficult, since AMF present seasonal dynamics, with higher activity in some periods of year (VIEIRA JÚNIOR et al., 2020), and can be dependent on the soil plant cover type, vegetation management, and carbon supply level (VAN DER HEYDE et al., 2017a).

\section{CONCLUSIONS}

The Cerrado forest presented higher sporulation of arbuscular mycorrhizal fungi (AMF) than the pasture and silvopasture ecosystems, regardless of the soil texture and season. The effect of the season and soil texture on the dynamics of AMF communities depends on the land use and 
management system. These edaphoclimatic attributes affect the spore density only in silvopasture and Cerrado forest ecosystems. Regarding the composition and diversity of AMF communities, the effect was more expressive in the Cerrado forest ecosystem. The AMF species with low sporulation are more affected by the season and soil texture. The species Glomus macrocarpum, Claroideoglomus etunicatum, Acaulospora mellea, Acaulospora scrobiculata, Glomus fasciculatum, and Paraglomus brazilianum are little affected by climate conditions, soil texture, and land management due to their widespread occurrence. The Shannon-Wiener diversity and Simpson dominance indexes, which are indicators of stability regarding the presence of AMF spores, showed that pasture and silvopasture ecosystems present higher variations in AMF diversity, with an antagonistic form (diversity and dominance).

\section{ACKNOWLEDGEMENTS}

The authors thank the Brazilian National Council for Scientific and Technological Development $(\mathrm{CNPq})$ for the financial support to this study and for granting a research scholarship.

\section{REFERENCES}

ASSIS, P. C. R. et al. Fungos micorrízicos arbusculares em campos de murundus após a conversão para sistemas agrícolas no cerrado. Revista Brasileira Ciência do Solo, 38: 1703-1711, 2014.

AZEVEDO, E. J. C. et al. Arbuscular Micorrizal Fungi and Farm Management Practices. World Journal of Agriculture and Soil Science, 2: 1-10, 2019.

BARBOSA, M. V. et al. Do different arbuscular mycorrhizal fungi affect the formation and stability of soil aggregates? Ciência e Agrotecnologia, 43: e003519, 2019.

BARROS, F. M. R. et al. Silvopastoral systems drive the nitrogen-cycling bacterial community in soil. Ciência e Agrotecnologia, 42: 281-290, 2018.

BONFIM, J. A. et al. Fungos micorrízicos arbusculares (FMA) e aspectos fisiológicos em cafeeiros cultivados em sistema agroflorestal e a pleno sol. Bragantia, 69: 201-206, 2010

CARVALHO, F. et al. The mosaic of habitats in the high-altitude Brazilian rupestrian fields is a hotspot for arbuscular mycorrhizal fungi. Applied Soil
Ecology, 52: 9-19, 2012.

CHEN, M. et al. Beneficial services of arbuscular mycorrhizal fungi - from ecology to application. Frontiers in Plant Science, 9: 1270, 2018.

COUTINHO, E. S. et al. Arbuscular Mycorrhizal Fungi in the Rhizosphere of Saplings Used in the Restoration of the Rupestrian Grassland. Ecological Restoration, 37: 152-162, 2019a.

COUTINHO, E. S. et al. Soil constraints for arbuscular mycorrhizal fungi spore community in degraded sites of rupestrian grassland: Implications for restoration. European Journal of Soil Biology, 90: 51-57, 2019b.

CORDEIRO, M. A. S. et al. Colonização e densidade de esporos de fungos micorrízicos em dois solos do cerrado sob diferentes sistemas de manejo. Pesquisa Agropecuária Tropical, 35:147-153, 2005

CRISTO, S. C.; FORS, R. O.; CARVALHO, A. G de Diversity of arbuscular mycorrhizal fungi in pasture areas in the Serra do Itajai National Park. Revista Brasileira de Ciências Agrárias, 13: e5513, 2018.

CHEN, M. et al. Beneficial Services of Arbuscular Mycorrhizal Fungi - From Ecology to Application. Frontiers in Plant Science, 9: 1-14, 2018.

CUNHA, A. R.; SHÖFFEL, E. R. The evapotranspiration in climate classification. In: GIACOMO, A. G. (Ed.). Evapotranspiration measurements to agricultural and environmental applications. Slavka Krautzeka, Rijeka: InTech, 2011. v. 1, cap. 20, p. 391-410.

DANTAS B. L. et al. Diversidade de fungos micorrízicos arbusculares em pomar orgânico no semiárido cearense. Ciência Rural, 45: 1-7, 2015.

DONAGEMA, G. K. et al. Manual de métodos de análise de solo. 2. ed. Rio de Janeiro, RJ: Embrapa Solos, 2011. 230 p.

FERREIRA, D. A.; CARNEIRO, M. A. C.; SAGGIN JUNIOR, O. J. Fungos micorrízicos arbusculares em um latossolo vermelho sob manejos e usos no cerrado. Revista Brasileira de Ciência do Solo, 36: 51-61, 2012.

GERDEMANN, J. W.; NICOLSON, T. H. Spores of mycorrhizal endogone species extracted from soil by wet-sieving and decanting. Transactions of British Mycological Society, 46: 235-244, 1963. 
INVAM - International culture collection of (vesicular) arbuscular mycorrhizal fungi. Species Descriptions. Disponível em: <http:// fungi.invam.wvu.edu/the-fungi/speciesdescriptions.html>. Acesso em: 07 ago. 2021.

JOSÉ, S.; DOLLINGER, J. Silvopasture: a sustainable livestock production system. Agroforestry Systems, 93: 1-9, 2019.

LOSS, A. et al. Atributos físicos e químicos do solo em sistemas de consórcio e sucessão de lavoura, pastagem e silvipastoril em Santa Teresa, ES. Bioscience Journal, 30: 1347-1357, 2014.

MAIA, L. C. et al. Species diversity of Glomeromycota in Brazilian biomes. Sydowia, 72: 181-205, 2020.

MEHROTRA, V. S. Arbuscular mycorrhizal associations of plants colonizing coal mine spoil in India. Journal of Agricultural Science, 130: 125 133, 1998.

MELO, C. D. et al. Species composition of arbuscular mycorrhizal fungi differ in semi-natural and intensively managed pastures in an isolated oceanic island (Terceira, Azores). Symbiosis, 64: 73 $-85,2014$.

MIGUEL, D. L. et al. Soil microbiological properties and enzyme activity in agroforestry systems compared with monoculture, natural regeneration, and native Caatinga. Bioscience Journal, 36: 1-16, 2020.

MIRANDA, E. M.; SILVA, E. M. R.; SAGGINJÚNIOR, O. J. Comunidades de fungos micorrízicos arbusculares associados ao amendoim forrageiro em pastagens consorciadas no Estado do Acre, Brasil. Acta Amazonica, 40: 13-22, 2010.

MOEBIUS-CLUNE, D. J. et al. Arbuscular mycorrhizal fungi associated with a single agronomic plant host across the landscape: Community differentiation along a soil textural gradient. Soil Biology and Biochemistry, 64, 191199, 2013.

MOREIRA, F. M. S.; SIQUEIRA, J. O. Microbiologia e Bioquímica do solo. Lavras: Universidade Federal de Lavras, 2006. 523 p.

NICODEMO, M. L. F. et al. Sistemas silvipastoris: introdução de árvores na pecuária do CentroOeste brasileiro. Campo Grande, PB: Embrapa Gado de Corte, 2004. 37 p.

PEREIRA, C. M. R. et al. Management practices may lead to loss of arbuscular mycorrhizal fungal diversity in protected areas of the Brazilian Atlantic Forest. Fungal Ecology, 34: 50-58, 2018.

PEZARICO C. R. et al. Indicadores de qualidade do solo em sistemas agroflorestais. Revista de Ciências Agrárias, 56:40-7, 2013.

RODRIGUES, L. A.; SILVA, D. K.; YAHO-MELO, A. M. Arbuscular Mycorrhizal Fungal Assemblages in Conservation Unit of Atlantic Forest Areas Under Native Vegetation and Natural Regeneration. Microbial Ecology, 82:122-134, 2021.

SANTOS, R. S..; SCORIZA, R. N.; FERREIRA, J. S. Fungos Micorrízicos Arbusculares em Diferentes Coberturas Florestais em Vitória da Conquista, Bahia. FLORAM, 20: 344-350, 2013.

SCHENCK, N. C.; PEREZ, Y. A manual of identification of vesicular-arbuscular mycorrhizal fungi, 2. ed. Gainesville: University of Florida, 1988. $241 \mathrm{p}$

SILVA, C. F. et al. Arbuscular mycorhizal fungal communities and soil organic matter in pasture and analog agroforestry systems. Revista Brasileira de Ciências Agrárias, 16: e8942, 2021.

SOUSA, C. S. et al. Arbuscular mycorrhizal fungi in successional stages of caatinga in the semi-arid region of Brazil. Ciência Florestal, 24: 137-148, 2014.

STÜRMER, S. L.; SIQUEIRA, J. O. Species richness and spore abundance of arbuscular mycorrhizal fungi across distinct land uses in Western Brazilian Amazon. Mycorrhiza, 21: 255267,2011

VAN DER HEYDE, M. et al. Arbuscular mycorrhizal fungus responses to disturbance are context-dependent. Mycorrhiza, 27: 431-440, $2017 \mathrm{a}$.

VAN DER HEYDE, M. et al. Longterm effects of grazing on arbuscular mycorrhizal fungi. Agriculture, Ecosystems and Environment, 243: 27-33, 2017b.

VELÁZQUEZ, M. S.; CABELlO, M. N.; BARRERA, M. Composition and structure of arbuscular-mycorrhizal communities in El Palmar National Park, Argentina. Mycologia, 105: 509-520, 2013.

VIEIRA, L. C. et al. Changes in an Arbuscular Mycorrhizal Fungi Community Along an Environmental Gradient. Plants, 9: 52, 2020.

VIEIRA JÚNIOR et al. Seasonal Variation in 
Mycorrhizal Community of Different Cerrado Phytophysiomies. Frontiers in Microbiology, 11:19, 2020.

WHEATERS, K. C.; STRAVER, D. L.; LIKENDS, G. E. Fundamentos de ciência dos ecossistemas. São Paulo: Elsevier, 2015. 340 p.

WINAGRASKI, E. et al. Diversity of arbuscular mycorrhizal fungi in forest ecosystems of Brazil: A review. Cerne, 25: 25-35, 2019. 